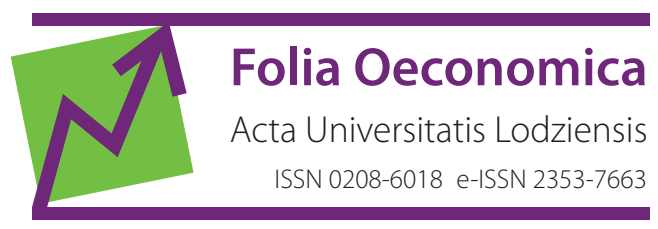

www.czasopisma.uni.lodz.pl/foe/

$3(348) 2020$

DOI: http://dx.doi.org/10.18778/0208-6018.348.06

\author{
Anna Mirczak \\ Uniwersytet Pedagogiczny w Krakowie, Instytut Spraw Społecznych, Katedra Gerontologii \\ Społecznej i Pedagogiki Pracy, anna.mirczak@gmail.com
}

\title{
Analiza jakości życia zależnej od stanu zdrowia starszych mieszkańców wsi ${ }^{1}$
}

Streszczenie: $W$ związku z postępującym procesem starzenia się społeczeństwa, a tym samym wzrostem liczby osób przewlekle chorych, nadrzędnym celem opieki zdrowotnej stało się nie tylko wydłużanie życia, ale także poprawa jego jakości oraz utrzymanie w starszym wieku względnej niezależności i aktywnego uczestnictwa w życiu społecznym. Najważniejszym czynnikiem determinującym jakość życia jest zdrowie, dlatego też w obrębie tego pojęcia używany jest termin „jakość życia uwarunkowana stanem zdrowia", oznaczający jakość życia wyznaczoną stanem zdrowia, obecnymi chorobami oraz naturalnym procesem starzenia.

Celem głównym prezentowanej pracy było zbadanie jakości życia uwarunkowanej stanem zdrowia osób starszych mieszkających na wsi oraz określenie jej determinantów.

Grupę badanych stanowiły 203 osoby w wieku 65 lat i więcej, mieszkające na obszarach wiejskich województwa małopolskiego. Analizę zebranego materiału badawczego wykonano z wykorzystaniem pakietu statystycznego IBM SPSS 19 dla Windows. Jako poziom istotności dla testowanych hipotez zerowych przyjęto wartość 0,05.

Badane osoby starsze mieszające na wsi istotnie lepiej oceniały wymiar psychiczny jakości życia uwarunkowanej stanem zdrowia niż wymiar fizyczny. Do czynników determinujących tę ocenę należały: płeć, wiek, sytuacja rodzinna, warunki mieszkaniowe i sytuacja materialna, stopień powiązania w przeszłości z rolnictwem, stan zdrowia, sprawność funkcjonalna, ryzyko niedożywienia, rodzaj otrzymywanego wsparcia oraz poziom satysfakcji życiowej respondentów.

Słowa kluczowe: jakość życia uwarunkowana stanem zdrowia, osoby starsze, obszary wiejskie

JEL: $\mid 10,114,118$

1 Niepublikowane fragmenty maszynopisu pracy doktorskiej A. Mirczak, Jakość życia uwarunkowana stanem zdrowia osób starszych mieszkających na obszarach wiejskich, Uniwersytet Jagielloński, Collegium Medicum, Wydział Lekarski, Kraków 2013. 


\section{Wprowadzenie}

Zakres działań istotnych z punktu widzenia zdrowia publicznego w Polsce precyzuje Narodowy Program Zdrowia na lata 2016-2020 (Rozporządzenie Rady Ministrów, 2016). Jego głównym celem jest wydłużenie życia, poprawa zdrowia i związanej z nim jakości życia ludności oraz zmniejszanie nierówności społecznych w zdrowiu. W zależności od grupy odbiorców i ich problemów cel główny ma konkretne uszczegółowienie. W przypadku osób starszych jest to tworzenie warunków do ich zdrowego i aktywnego życia, czyli tworzenie środowiska sprzyjającego pomyślnemu starzeniu się w dobrej jakości życia. Sama jakość życia (Quality of Life - QL) jest pojęciem trudnym do jednoznacznego zdefiniowania. W zależności od dziedziny naukowej różne aspekty mogą świadczyć o jakości. W ujęciu nauk społecznych z jakością życia związane są takie czynniki środowiskowe jak: miejsce zamieszkania, sposób spędzania czasu wolnego, środowisko pracy i dochód (Campbell, Converse, Rodgers, 1976). Inna hipoteza zakłada, że najważniejsze w jakości życia jest poczucie zaspokojenia fizycznych, psychicznych i społecznych potrzeb ludzkich według hierarchii potrzeb Maslowa, a także aktywność i stan cywilny (Hornquist, 1980). Na gruncie nauk medycznych istnieje koncepcja jakości życia uwarunkowanej stanem zdrowia (Health Related Quality of Life - HRQoL), która zgodnie z definicją Schippera (1990) oznacza funkcjonalny efekt choroby i jej leczenia odbierany przez pacjenta. Celem analizy HRQoL jest poznanie subiektywnego stanu zdrowia jednostki przez pryzmat doświadczanej choroby oraz rozpoznanie czynników determinujących jakość życia. Ponadto takie spojrzenie na jakość życia pozwala rozpoznać pewne zasadnicze obszary funkcjonowania osoby chorej, takie jak (Ostrzyżek, Marcinkowski, 2012):

1) stan fizyczny, w tym sprawność ruchowa,

2) stan psychiczny,

3) warunki społeczno-ekonomiczne,

4) doznania somatyczne (odczuwane dolegliwości i objawy chorobowe).

Pomiar HRQoL w grupie osób starszych może być utrudniony ze względu na współwystępujące choroby i dolegliwości, które implikują pewne zaburzenia poznawcze. Niemniej jednak badania tego typu mają dużą wartość diagnostyczną i prognostyczną. Pozwalają bowiem zbadać stopień niesprawności i zależności seniora od otoczenia w prowadzeniu codziennej aktywności, a także poznać jego indywidualne potrzeby i oczekiwania. Stanowią także ważny element promowania aktywnego starzenia się oraz włączania osób starszych w kontekst życia społecznego w poczuciu autonomii i niezależności (Guimaraes-Lima i wsp., 2009). Sukcesywny pomiar HRQoL ma kluczowe znaczenie dla systemu opieki zdrowotnej. Decydenci i profesjonaliści medyczni, znając społeczny, fizyczny i psychiczny kontekst uwarunkowań zdrowia i choroby osób starszych, mogą przygotowywać programy zdrowotne adekwatne do ich potrzeb. Miejsce zamieszkania 
(miasto $v s$ wieś) jest istotnym czynnikiem determinującym ocenę jakości życia. Osoby starsze zamieszkujące obszary wiejskie, ze względu na pewne uwarunkowania kulturowe, charakteryzują się określonym sposobem myślenia, w którym wartościami priorytetowymi często są rodzina i praca na roli. Dodatkowo ciężkie doświadczenia związane z wybuchem II wojny światowej wykształciły u tych seniorów pewne postawy i wzory zachowań, które rzutują na ich obecną sytuację zdrowotną i społeczno-ekonomiczną (Tryfan, 1993). Prowadzone dotychczas badania pokazują, że osoby starsze mieszkające na terenach wiejskich gorzej oceniają swoją HRQoL w wyniku nakładania się pewnych swoistych czynników społeczno-ekonomicznych typowych dla tych obszarów. Zalicza się do nich między innymi: wykluczenie społeczne i geograficzne, ograniczony dostęp do placówek ochrony zdrowia oraz niski status socjoekonomiczny (Benjamin-Coleman, Alexy, 1999; Goins, Mitchell, 1999; Borders, Aday, 2004). Niska HRQoL seniorów mieszkających na wsi podyktowana jest także nieufnością do sektora opieki zdrowotnej i profesjonalistów medycznych - preferują oni tradycyjne metody lecznicze, bazujące na wiedzy przekazywanej w najbliższym kręgu rodzinnym (Magilvy, Congdon, 2000). Literatura przedmiotu sugeruje, że w ocenie HRQoL pomiędzy starszymi kobietami i mężczyznami zamieszkującymi obszary wiejskie występują pewne dysproporcje na niekorzyść tych pierwszych (Walters, Murno, Brazjer, 2001).

Celem przedstawionych analiz było zbadanie jakości życia uwarunkowanej stanem zdrowia osób starszych mieszkających na wsi oraz określenie jej determinantów. Na tej podstawie sformułowano kilka problemów badawczych, które miały ocenić, w jakim stopniu charakterystyka społeczno-demograficzna, stan zdrowia (liczba chorób i dolegliwości oraz stan funkcjonalny i umysłowy), stopień niedożywienia, sytuacja rodzinna, materialna i zawodowa (stopień powiązania z rolnictwem i rodzaj wykonywanego w przeszłości zawodu), rodzaj otrzymywanego wsparcia oraz satysfakcja życiowa badanych determinują ich jakość życia uwarunkowaną stanem zdrowia.

\section{Materiał i metody}

Prezentowane wyniki uzyskano w trakcie prowadzenia badań w ramach przygotowywania pracy doktorskiej na temat jakość życia uwarunkowana stanem zdrowia osób starszych mieszkających na obszarach wiejskich w Zakładzie Socjologii Medycyny Katedry Epidemiologii i Medycyny Zapobiegawczej Uniwersytetu Jagiellońskiego Collegium Medium w Krakowie.

Badaniem objęto 203 osoby w wieku 65 lat i więcej, mieszkające w wybranych miejscowościach wiejskich województwa małopolskiego. Do zebrania materiału badawczego wykorzystano metodę sondażu diagnostycznego. Dane o jednostkach zgromadzono techniką wywiadu za pomocą ustrukturyzowanego kwestionariu- 
sza. Wywiady prowadzono, wykorzystując technikę CAPI (Computer-Assisted Personal Interviewing), polegającą na osobistym wywiadzie wspomaganym komputerowo.

Kwestionariusz wywiadu składał się z kilkunastu części. Pierwsza część zawierała pytania charakteryzujące badaną grupę pod kątem społeczno-demograficznym, a następne dotyczyły odpowiednio: sytuacji rodzinnej, sytuacji zawodowej i materialnej, warunków mieszkaniowych, stanu zdrowia (w tym sprawności funkcjonalnej w zakresie wykonywania czynności dnia codziennego, mierzonej skalą GARS - Groningen Activity Restrain Scale) (Kempen i wsp., 1996), dostępności i zapotrzebowania na opiekę zdrowotną, stylu życia (sposobu spędzania czasu wolnego), oceny ryzyka niedożywienia i zwyczajów żywieniowych (skala NSI - Determine Checklist - Nutritional Screening Initiative „Determine Your Nutritional" Health Checklist) (Barrocas i wsp., 1996, w wersji polskiej za Wojszel, 2009), wsparcia społecznego (skala MOS SSS - The Medical Outcomes Study Social Support Survey) (Sherbourne, Stewart, 1991) oraz satysfakcji życiowej (skala LSITA SF - Life Satisfaction Index for the Third Age-Short Form) (Barrett, Murk, 2006). Pytania zawarte w kwestionariuszu były w większości zamknięte. Do oceny jakości życia uwarunkowanej stanem zdrowia badanych osób starszych wykorzystano skalę SF-36 - Short Form-36 Health Survey (Ware, Sherbourne, 1992). Kwestionariusz zawierał 36 pytań pozwalających mierzyć osiem wymiarów HRQoL:

1) funkcjonowanie fizyczne (stan funkcjonalny),

2) funkcjonowanie społeczne (towarzyskie),

3) ograniczenie w pełnieniu ról z powodu stanu zdrowia,

4) ograniczenie w pełnieniu ról z powodu stanu emocjonalnego,

5) zdrowie psychiczne,

6) witalność,

7) ból fizyczny,

8) ogólną percepcję stanu zdrowia.

Wskaźnik jakości życia uwarunkowanej stanem zdrowia stanowi sumę punktów uzyskanych z oceny poszczególnych wymiarów. Zgodnie z polską wersją kwestionariusza SF-36 (Marcinowicz, Sienkiewicz, 2003) najwyższa wartość punktowa danego wymiaru oznacza najniższy stopień oceny jakości życia, natomiast najniższa wartość punktowa tożsama jest z najwyższym poziomem jakości życia. Kwestionariusz SF-36 jest wykorzystywany do monitorowania zdrowia populacji oraz pomiaru zdrowia w kontekście jakości życia respondentów. Skala pozwala także obliczyć dwa wymiary jakości życia uwarunkowanej stanem zdrowia: fizyczny i psychiczny. W skład wymiaru fizycznego wchodzą takie podskale jak: funkcjonowanie fizyczne, ograniczenie w pełnieniu ról z powodu stanu zdrowia, ból fizyczny oraz ogólna percepcja stanu zdrowia. Natomiast wymiar psychiczny złożony jest z podskal badających funkcjonowanie społeczne (towarzyskie), ogra- 
niczenia w pełnieniu ról z powodu stanu emocjonalnego, zdrowie psychiczne oraz witalność. Trafność i rzetelność skali w warunkach polskich została oceniona wysoko (Marcinowicz, Sienkiewicz, 2003).

W niniejszym artykule dla każdego wymiaru HRQoL odpowiedzi zostały zsumowane i przekodowane na skali od 0 do 100 punktów w taki sposób, aby wyższa wartość punktowa oznaczała lepszą jakość życia (brak ograniczeń). W przypadku wymiaru zdolności do pełnienia ról pomimo ograniczeń stanu emocjonalnego większość badanych mieściła się w kategorii osób niemających żadnych ograniczeń. Dlatego też w celu dalszej analizy zmienna ta potraktowana została jako porządkowa, różnicująca trzy kategorie respondentów: o pełnych ograniczeniach (0 pkt), o częściowych ograniczeniach (33,3 i 66,6 pkt) oraz niemających żadnych ograniczeń (100 pkt) (Tabela 1).

Tabela 1. Rozkład poziomu ograniczeń w wymiarze zdolności do pełnienia ról pomimo ograniczeń stanu emocjonalnego

\begin{tabular}{|l|r|r|r|}
\hline \multicolumn{2}{|c|}{ Poziom ograniczeń } & $n$ & \% \\
\hline Całkowite ograniczenie & 0,00 & 52 & 25,6 \\
\hline Częściowe ograniczenie & 33,33 & 19 & 9,4 \\
\cline { 2 - 4 } & 66,67 & 26 & 12,8 \\
\hline Brak ograniczeń & 100,00 & 106 & 52,2 \\
\hline
\end{tabular}

Źródło: opracowanie własne

W celu określenia niezależnych determinantów zmiennej zależnej (skali SF-36 składającej się z ośmiu podskal) stworzono wieloczynnikowe modele regresji liniowej, standaryzowane na: płeć, wiek, stan cywilny, wykształcenie, posiadanie i liczbę dzieci, samotne zamieszkiwanie, częstość samotnego przebywania w domu, poczucie osamotnienia, liczbę współmieszkańców i relacje z nimi, poważanie i poszanowanie $\mathrm{w}$ domu, pracę $\mathrm{w}$ gospodarstwie rolnym $\mathrm{w}$ przeszłości, wiek przejścia na emeryturę, wysokość miesięcznego dochodu, obciążenie finansowe wydatkami na opłaty mieszkaniowe, żywność, leki, środki czystości i rozrywkę, kwotę przeznaczaną na leki w skali miesiąca, samoocenę sytuacji materialnej i mieszkaniowej, wielkość mieszkania (liczba izb i metraż), preferencję zamieszkania (miasto lub wieś), samoocenę stanu zdrowia, liczbę chorób, częstość dolegliwości, choroby układu krążenia, pokarmowego, oddechowego, moczowo-płciowego, kostno-stawowego, zadowolenie z funkcjonującego w Polsce systemu opieki zdrowotnej, ryzyko niedożywienia mierzone skalą NSI Determine Checklist oraz aktualne problemy (zdrowotne, materialne, samotność, brak wsparcia i szacunku itp.). Modele tworzono poprzez dołączanie kolejnych zmiennych niezależnych. Zmienne istotnie wpływające na zmienną zależną zostawiano w modelu, natomiast zmienne niezależne, które były nieistotne, były z niego wyłączane. W analizowanych modelach, gdzie związek między zmienną zależną i niezależną 
ilościową był liniowy, zmienna niezależna była analizowana w oryginalnej postaci, w przeciwnym przypadku zmienna niezależna była kategoryzowana. Wartość wieloczynnikowych modeli regresji liniowej, które uzyskano w trakcie analizy, oceniano za pomocą: skorygowanego współczynnika determinacji $\mathrm{R}^{2}$, testem $\mathrm{F}$, testem t-Studenta (istotność poszczególnych zmiennych) oraz testem Shapiro-Wilka (normalność rozkładu reszt).

Zebrane dane były analizowane z wykorzystaniem pakietu statystycznego IBM SPSS Statistics $20 \mathrm{z}$ zastosowaniem wielowymiarowych technik analizy. Istnienie różnic i siłę związku między zmiennymi szacowano na poziomie istotności $p=0,05$.

\section{Wyniki}

Grupę badanych stanowiło 61,6\% kobiet i 38,4\% mężczyzn w wieku wynoszącym średnio 75,5 lat $(S D=5,7)$. Większość badanych miała wykształcenie podstawowe (63\%). Dominowały osoby owdowiałe, przy czym ich odsetek był prawie dwukrotnie wyższy w przypadku kobiet (72\%) w odniesieniu do mężczyzn (28\%). Prawie trzy czwarte respondentów (71,9\%) pracowało w przeszłości w gospodarstwie rolnym (Tabela 2). Badani seniorzy w większości mieli dzieci $(89,2 \%)$ i wnuki $(83,7 \%)$ oraz zamieszkiwali zwykle z innymi członkami rodziny $(75,9 \%)$.

Tabela 2. Charakterystyka społeczno-demograficzna badanej grupy $(n=203)$

\begin{tabular}{|c|c|c|c|}
\hline \multicolumn{2}{|r|}{ Zmienne } & \multirow{2}{*}{$\begin{array}{c}\boldsymbol{n} \\
125 \\
\end{array}$} & \multirow{2}{*}{$\begin{array}{r}\% \\
61,6\end{array}$} \\
\hline Płeć & Kobiety & & \\
\hline Prec & Mężczyźni & 78 & 38,4 \\
\hline \multirow{5}{*}{ Wiek } & 65-69 lat & 34 & 16,7 \\
\hline & 70-74 lat & 43 & 21,2 \\
\hline & \begin{tabular}{|l|}
$75-79$ lat \\
\end{tabular} & 75 & 36,9 \\
\hline & 80-84 lat & 39 & 19,2 \\
\hline & 85 i więcej & 12 & 5,9 \\
\hline \multirow{4}{*}{ Wykształcenie } & Podstawowe niepełne & 22 & 10,8 \\
\hline & Podstawowe & 128 & 63,1 \\
\hline & Zasadnicze zawodowe & 37 & 18,2 \\
\hline & Średnie & 16 & 7,9 \\
\hline \multirow{4}{*}{ Stan cywilny } & Kawaler/Panna & 19 & 9,4 \\
\hline & Żonaty/Zamężna & 80 & 39,4 \\
\hline & Rozwiedziony/a/W separacji & 8 & 3,9 \\
\hline & Wdowiec/Wdowa & 96 & 47,3 \\
\hline \multirow{2}{*}{ Praca w rolnictwie } & Tak & 146 & 71,9 \\
\hline & Nie & 57 & 28,1 \\
\hline
\end{tabular}

Źródło: opracowanie własne 
Średnia liczba chorób występująca u badanych seniorów wynosiła 5,3 $(S D=2,5)$ i była zależna od płci. W grupie kobiet średnia liczba schorzeń była istotnie wyższa niż u mężczyzn $(5,6 \pm 2,4$ vs $4,7 \pm 2,6)$. Występujące choroby implikowały pewne dolegliwości zdrowotne w grupie badanych seniorów. Do najczęstszych należały: bóle kręgosłupa, problemy z wczesnym budzeniem się, pogorszenie ostrości widzenia oraz widzenia na bliskie odległości, osłabienie mięśni, duszność po wysiłku, problemy z nocnym budzeniem się i z zasypianiem oraz gwałtowne skoki ciśnienia tętniczego krwi.

Respondenci oceniali swoje zdrowie głównie na poziomie średnim (45,3\%), następnie złym $(29,6 \%)$ i dobrym $(25,1 \%)$. Schorzenia, które występowały najczęściej w badanej grupie seniorów, to: nadciśnienie tętnicze krwi (67,5\%), choroba zwyrodnieniowa stawów z silnym odczynem bólowym $(44,8 \%)$, miażdżyca $(43,3 \%)$ oraz zaćma starcza $(40,4 \%)$. Pewne jednostki chorobowe istotnie częściej występowały wśród osób pracujących w przeszłości w gospodarstwie rolnym w porównaniu do osób nigdy niezwiązanych z rolnictwem. Należały do nich choroby: układu krążenia, naczyń (tętnic i żył), układu pokarmowego, a także zaburzenia sensoryczne.

Analiza zebranego materiału badawczego pokazała, że badani seniorzy mieszkający na wsi najlepiej ocenili jakość życia w wymiarze: zdolności do pełnienia ról pomimo ograniczeń stanu emocjonalnego (100), zdrowia psychicznego $(50,7)$, funkcjonowania bez ograniczeń w życiu towarzyskim $(45,3)$ oraz wigoru i energii (45). Gorsze noty dotyczyły odpowiednio takich wymiarów jakości życia jak: ogólna percepcja zdrowia $(38,8)$, funkcjonowanie pomimo występujących objawów bólowych $(33,5)$, stan funkcjonalny (35), jak również zdolność do pełnienia ról pomimo ograniczeń w stanie zdrowia (25).

Według wieloczynnikowego modelu regresji liniowej osoby, które często pozostawały same $\mathrm{w}$ domu oraz były w grupie wysokiego ryzyka niedożywienia, oceniały istotnie gorzej jakość życia w wymiarze ogólnej percepcji zdrowia w porównaniu do respondentów, którzy rzadko przebywali sami w domu, a także o średnim ryzyku niedożywienia lub bez ryzyka niedożywienia. Natomiast seniorzy, dla których niepełnosprawność wynikająca z wieku ani ciężka sytuacja materialna nie stanowiły największych problemów w chwili badania, podkreślali istotnie wyższą jakość życia w wymiarze ogólnej percepcji zdrowia niż osoby, dla których były to poważne problemy. Jakość życia w wymiarze ogólnej percepcji zdrowia badanych w istotnym stopniu zwiększała się wraz ze wzrostem ich sprawności funkcjonalnej oraz poziomem satysfakcji życiowej (Tabela 3).

Na jakość życia w wymiarze funkcjonalnym w istotnym stopniu wpływała płeć respondentów, a także wiek przejścia na emeryturę. Mężczyźni oraz ci, którzy później przeszli na emeryturę, charakteryzowali się lepszą jakością życia w tym wymiarze niż kobiety oraz osoby, które wiek emerytalny osiągnęły wcześniej. Ponadto osoby, dla których niepełnosprawność wynikająca z wieku ani brak 
wsparcia najbliższych nie stanowiły największego problemu w chwili badania, istotniej lepiej oceniały swoją jakość życia w wymiarze funkcjonalnym w porównaniu do respondentów, dla których były to poważne problemy. Seniorzy, którzy w chwili badania preferowali mieszkanie w mieście, podkreślali istotnie niższą jakość życia w wymiarze funkcjonalnym niż osoby, które nadal wolały mieszkać na wsi. Dodatkowo osoby, które cechowały się wysokim ryzykiem niedożywienia oraz u których występowały choroby układu krążenia i pokarmowego, istotnie gorzej oceniały jakość w wymiarze funkcjonalnym w zestawieniu z seniorami o średnim ryzyku niedożywienia lub bez ryzyka niedożywienia oraz niechorujących na schorzenia układu krążenia i pokarmowego. Jakość życia w wymiarze funkcjonalnym badanych osób starszych w istotnym stopniu zmniejszała się także wraz ze wzrostem średniej częstości dolegliwości występujących u respondentów oraz wraz ze wzrostem kwoty przeznaczanej przez nich na leki.

Tabela 3. Zmienne niezależne warunkujące jakość życia w wymiarze ogólnej percepcji zdrowia według modelu regresji liniowej

\begin{tabular}{|l|c|c|c|c|}
\hline \multicolumn{1}{|c|}{ Zmienne niezależne } & \multicolumn{1}{c|}{$\mathbf{B}$} & \multicolumn{2}{c|}{$\mathbf{9 5 \%} \boldsymbol{C I}$} & $\boldsymbol{p}$ \\
\hline Pozostawanie samemu w domu (często vs rzadko) & $-1,95$ & $-3,35$ & $-0,55$ & $<0,05$ \\
\hline $\begin{array}{l}\text { Ryzyko niedożywienia wg skali NSI Determine } \\
\text { Checklist (wysokie } v s \text { średnie i brak ryzyka) }\end{array}$ & $-6,06$ & $-11,23$ & $-0,9$ & $<0,05$ \\
\hline $\begin{array}{l}\text { Problem niepełnosprawności wynikającej z wieku } \\
\text { (nie } v s \text { tak) }\end{array}$ & 1,83 & 0,13 & 3,54 & $<0,05$ \\
\hline Ciężka sytuacja materialna (nie $v s$ tak) & 1,88 & 0,78 & 2,97 & $<0,05$ \\
\hline Stan funkcjonalny mierzony skalą GARS & 0,41 & 0,26 & 0,56 & $<0,05$ \\
\hline Satysfakcja życiowa mierzona skalą LSITA SF & 0,46 & 0,24 & 0,68 & $<0,05$ \\
\hline
\end{tabular}

$B$ - współczynnik regresji, 95\% Cl - zakres przedziału ufności dla B.

Źródło: opracowanie własne

Tabela 4. Zmienne niezależne warunkujące jakość życia w wymiarze stanu funkcjonalnego według modelu regresji liniowej

\begin{tabular}{|l|r|r|r|c|}
\hline \multicolumn{1}{|c|}{ Zmienne niezależne } & \multicolumn{1}{c|}{$\boldsymbol{B}$} & \multicolumn{2}{c|}{$\mathbf{9 5 \%} \boldsymbol{C I}$} & $\boldsymbol{p}$ \\
\hline Płeć (M $v s \mathrm{~K})$ & 6,48 & 1,91 & 11,05 & $<0,05$ \\
\hline Wiek przejścia na emeryturę & 3,07 & 1,07 & 5,07 & $<0,05$ \\
\hline Kwota przeznaczana na leki w skali miesiąca & $-3,04$ & $-5,15$ & $-0,93$ & $<0,05$ \\
\hline $\begin{array}{l}\text { Problem niepełnosprawności wynikającej z wieku } \\
\text { (nie } v s \text { tak) }\end{array}$ & 4,23 & 2,26 & 6,20 & $<0,05$ \\
\hline Problem braku wsparcia (nie $v s$ tak) & 3,65 & 0,66 & 6,63 & $<0,05$ \\
\hline Preferencja zamieszkania (miasto $v s$ wieś) & $-8,54$ & $-14,45$ & $-2,63$ & $<0,05$ \\
\hline Choroby układu krążenia (tak $v s$ nie) & $-5,20$ & $-8,56$ & $-1,85$ & $<0,05$ \\
\hline Choroby układu pokarmowego (tak $v s$ nie) & $-2,95$ & $-5,50$ & $-0,40$ & $<0,05$ \\
\hline
\end{tabular}




\begin{tabular}{|l|c|c|c|c|}
\hline \multicolumn{1}{|c|}{ Zmienne niezależne } & B & \multicolumn{2}{c|}{$\mathbf{9 5 \%} \boldsymbol{C I}$} & $\boldsymbol{p}$ \\
\hline $\begin{array}{l}\text { Ryzyko niedożywienia wg skali NSI Determine } \\
\text { Checklist (wysokie } v s \text { średnie i brak ryzyka) }\end{array}$ & $-6,98$ & $-11,99$ & $-1,98$ & $<0,05$ \\
\hline Średnia częstość wszystkich dolegliwości & $-12,26$ & $-17,13$ & $-7,39$ & $<0,05$ \\
\hline
\end{tabular}

B - współczynnik regresji, 95\% Cl - zakres przedziału ufności dla B.

\section{Źródło: opracowanie własne}

Jak przedstawia Tabela 5, mężczyźni istotnie lepiej oceniali jakość życia w wymiarze zdolności do pelnienia ról pomimo ograniczeń w stanie zdrowia niż kobiety. Jakość życia w tym wymiarze w istotnym stopniu zwiększała się wraz ze wzrostem sprawności funkcjonalnej respondentów oraz otrzymywanym wsparciem instrumentalnym. Natomiast w przypadku liczby współmieszkańców tendencja była odwrotna, ponieważ im większa była ich liczba, tym niższa jakość życia w wymiarze zdolności do pełnienia ról pomimo ograniczeń w stanie zdrowia. Dodatkowo osoby zgłaszające choroby układu krążenia cechowała istotnie niższa jakość życia w tym wymiarze w porównaniu do seniorów niechorujących na tego typu schorzenia.

\section{Tabela 5. Zmienne niezależne warunkujące jakość życia w wymiarze zdolności do pełnienia ról pomimo ograniczeń w stanie zdrowia według modelu regresji liniowej}

\begin{tabular}{|l|r|r|r|c|}
\hline \multicolumn{1}{|c|}{ Zmienne niezależne } & \multicolumn{1}{c|}{$\boldsymbol{B}$} & \multicolumn{2}{c|}{$\mathbf{9 5 \%} \boldsymbol{C I}$} & $\boldsymbol{p}$ \\
\hline Płeć (M vs K) & 10,29 & 1,74 & 18,85 & $<0,05$ \\
\hline Liczba współmieszkańców & $-4,10$ & $-7,31$ & $-0,88$ & $<0,05$ \\
\hline Choroby układu krążenia (tak $v$ s nie) & $-8,63$ & $-14,39$ & $-2,87$ & $<0,05$ \\
\hline Wsparcie instrumentalne wg skali MOS SSS & 0,39 & 0,15 & 0,63 & $<0,05$ \\
\hline Stan funkcjonalny mierzony skalą GARS & 1,39 & 1,07 & 1,71 & $<0,05$ \\
\hline
\end{tabular}

B - współczynnik regresji, 95\% Cl - zakres przedziału ufności dla B.

\section{Źródło: opracowanie własne}

Jakość życia w wymiarze zdolności do pełnienia ról pomimo ograniczeń stanu emocjonalnego $\mathrm{w}$ istotnym stopniu wzrastała wraz $\mathrm{z}$ wiekiem badanych. W przypadku zmiennych stan funkcjonalny i satysfakcja życiowa zaobserwowano tendencję podobną: im większa sprawność funkcjonalna seniorów oraz poziom satysfakcji życiowej, tym wyższa ich jakość życia w tym wymiarze (Tabela 6).

Zgodnie z wynikami przedstawionymi w tabeli 7 wykazano, że osoby, dla których niepełnosprawność wynikająca $\mathrm{z}$ wieku nie stanowiła $\mathrm{w}$ chwili badania największego problemu, istotnie lepiej oceniały swoją jakość życia w wymiarze funkcjonowania pomimo występujących objawów bólowych niż seniorzy, dla których był to poważny problem. Natomiast respondenci w grupie wysokiego ryzyka niedożywienia potwierdzali istotnie gorszą jakość życia w tym wymiarze w porównaniu do badanych bez ryzyka niedożywienia. Jakość życia seniorów 
w wymiarze funkcjonowania pomimo występujących objawów bólowych w istotnym stopniu obniżała się także wraz ze wzrostem średniej częstości dolegliwości i średniej liczby chorób u nich występujących. Tymczasem wraz ze wzrostem stopnia sprawności funkcjonalnej badanych osób starszych istotnie wzrastała ich jakość życia w analizowanym wymiarze.

Tabela 6. Zmienne niezależne warunkujące jakość życia w wymiarze zdolności do pełnienia ról pomimo ograniczeń stanu emocjonalnego według modelu regresji liniowej

\begin{tabular}{|l|c|c|c|c|}
\hline \multicolumn{1}{|c|}{ Zmienne niezależne } & $\boldsymbol{B}$ & \multicolumn{2}{c|}{$\mathbf{9 5 \%} \boldsymbol{C I}$} & $\boldsymbol{p}$ \\
\hline Wiek & 1,92 & 0,80 & 3,04 & $<0,05$ \\
\hline Stan funkcjonalny mierzony skalą GARS & 1,32 & 0,82 & 1,82 & $<0,05$ \\
\hline Satysfakcja życiowa mierzona skalą LSITA SF & 1,44 & 0,56 & 2,32 & $<0,05$ \\
\hline
\end{tabular}

B - współczynnik regresji, 95\% Cl - zakres przedziału ufności dla $B$.

Źródło: opracowanie własne

Tabela 7. Zmienne niezależne warunkujące jakość życia w wymiarze funkcjonowania pomimo występujących objawów bólowych według modelu regresji liniowej

\begin{tabular}{|l|r|r|r|c|}
\hline \multicolumn{1}{|c|}{ Zmienne niezależne } & \multicolumn{1}{c|}{$\boldsymbol{B}$} & \multicolumn{2}{c|}{$\mathbf{9 5 \%} \boldsymbol{C I}$} & $\boldsymbol{p}$ \\
\hline $\begin{array}{l}\text { Problem niepełnosprawności wynikającej z wieku } \\
\text { (nie } v s \text { tak) }\end{array}$ & 2,09 & 0,07 & 4,11 & $<0,05$ \\
\hline $\begin{array}{l}\text { Ryzyko niedożywienia wg skali NSI Determine } \\
\text { Checklist (wysokie } v \text { s brak ryzyka) }\end{array}$ & $-5,22$ & $-10,69$ & $-0,35$ & $<0,05$ \\
\hline Średnia częstość wszystkich dolegliwości & $-11,60$ & $-18,27$ & $-4,93$ & $<0,05$ \\
\hline Średnia liczba wszystkich chorób & $-1,19$ & $-2,34$ & $-0,05$ & $<0,05$ \\
\hline Stan funkcjonalny mierzony skalą GARS & 0,40 & 0,16 & 0,64 & $<0,05$ \\
\hline
\end{tabular}

$B$ - współczynnik regresji, 95\% Cl - zakres przedziału ufności dla B.

\section{Źródło: opracowanie własne}

Jakość życia w wymiarze funkcjonowania bez ograniczeń w życiu towarzyskim była oceniana istotnie gorzej przez osoby niepracujące w przeszłości w gospodarstwie rolnym niż przez respondentów związanych w przeszłości z rolnictwem. Ponadto seniorzy należący do grupy średniego ryzyka niedożywienia oraz chorujący na choroby układu kostno-stawowego potwierdzali istotnie niższą jakość życia w tym wymiarze w porównaniu do osób bez ryzyka niedożywienia i niezgłaszających schorzeń układu kostno-stawowego. Natomiast istotnie wyższą jakość życia podkreślali respondenci, którzy nie uskarżali się na problem braku wsparcia ze strony najbliższych w porównaniu do osób, dla których był to poważny problem. Dodatkowo im większy stopień sprawności funkcjonalnej badanych osób starszych oraz poziom ich satysfakcji życiowej, tym istotnie wyższa jakość życia w tym wymiarze (Tabela 8).

Jak pokazano w tabeli 9, mężczyźni oceniali istotnie wyżej jakość życia w wymiarze wigoru i energii w porównaniu do kobiet. Ponadto jakość życia w tym 
wymiarze w istotnym stopniu zwiększała się wraz ze wzrostem sprawności funkcjonalnej oraz poziomem satysfakcji życiowej seniorów. Poziom jakość życia badanych w analizowanym wymiarze rósł także istotnie wraz ze wzrostem liczby ich współmieszkańców. Natomiast osoby, które miały dzieci oraz w przeszłości nie pracowały w gospodarstwie rolnym, charakteryzowały się istotnie niższą jakością życia w omawianym wymiarze niż respondenci bezdzietni oraz związani w przeszłości z rolnictwem. Podobnie niższą jakością życia charakteryzowały się osoby, które zgłaszały choroby układu kostno-stawowego.

Tabela 8. Zmienne niezależne warunkujące jakość życia w wymiarze funkcjonowania bez ograniczeń w życiu towarzyskim według modelu regresji liniowej

\begin{tabular}{|l|r|r|r|c|}
\hline \multicolumn{1}{|c|}{ Zmienne niezależne } & \multicolumn{1}{c|}{$\boldsymbol{B}$} & \multicolumn{2}{c|}{$\mathbf{9 5 \%} \boldsymbol{C I}$} & $\boldsymbol{p}$ \\
\hline Praca w gospodarstwie rolnym (nie $v s$ tak) & $-6,55$ & $-12,28$ & $-0,82$ & $<0,05$ \\
\hline $\begin{array}{l}\text { Ryzyko niedożywienia wg skali NSI Determine } \\
\text { Checklist (średnie } v \text { s brak ryzyka) }\end{array}$ & $-6,15$ & $-11,1$ & $-1,21$ & $<0,05$ \\
\hline Problem braku wsparcia (nie $v$ s tak) & 3,83 & 0,85 & 6,81 & $<0,05$ \\
\hline Choroby układu kostno-stawowego (tak $v s$ nie) & $-4,18$ & $-6,81$ & $-1,55$ & $<0,05$ \\
\hline Stan funkcjonalny mierzony skalą GARS & 0,84 & 0,65 & 1,03 & $<0,05$ \\
\hline Satysfakcja życiowa mierzona skalą LSITA SF & 1,17 & 0,81 & 1,53 & $<0,05$ \\
\hline
\end{tabular}

B - współczynnik regresji, 95\% Cl - zakres przedziału ufności dla B.

Źródło: opracowanie własne

Tabela 9. Zmienne niezależne warunkujące jakość życia w wymiarze wigoru i energii według modelu regresji liniowej

\begin{tabular}{|l|r|r|r|c|}
\hline \multicolumn{1}{|c|}{ Zmienne niezależne } & \multicolumn{1}{c|}{$\boldsymbol{B}$} & \multicolumn{2}{c|}{$\mathbf{9 5 \%} \boldsymbol{C I}$} & $\boldsymbol{p}$ \\
\hline Płeć (M vs K) & 4,14 & 1,01 & 7,26 & $<0,05$ \\
\hline Posiadanie dzieci (tak $v s$ nie) & $-9,08$ & $-16,58$ & $-1,58$ & $<0,05$ \\
\hline Liczba współmieszkańców & 1,65 & 0,44 & 2,85 & $<0,05$ \\
\hline Praca w gospodarstwie rolnym (nie $v s$ tak) & $-7,75$ & $-11,55$ & $-3,94$ & $<0,05$ \\
\hline Choroby układu kostno-stawowego (tak $v s$ nie) & $-2,44$ & $-4,13$ & $-0,75$ & $<0,05$ \\
\hline Stan funkcjonalny mierzony skalą GARS & 0,27 & 0,14 & 0,39 & $<0,05$ \\
\hline Satysfakcja życiowa mierzona skalą LSITA SF & 0,78 & 0,54 & 1,01 & $<0,05$ \\
\hline
\end{tabular}

B - współczynnik regresji, 95\% Cl - zakres przedziału ufności dla B.

\section{Źródło: opracowanie własne}

Wieloczynnikowej analizie poddano także skalę zdrowia psychicznego. Uzyskane wyniki wskazały, iż osoby niepracujące w przeszłości w gospodarstwie rolnym istotnie gorzej oceniały swoją jakość życia w wymiarze zdrowia psychicznego niż respondenci, którzy byli związani w przeszłości z rolnictwem. Także im większa była średnia częstość wszystkich dolegliwości występujących u badanych se- 
niorów, tym niższa ich jakość życia w tym wymiarze. Natomiast osoby, które nie uskarżały się w chwili badania na brak wsparcia ze strony najbliższych, cechowała istotnie wyższa jakość życia w wymiarze zdrowia psychicznego w porównaniu do seniorów, dla których był to poważny problem. Ponadto wraz ze wzrostem satysfakcji życiowej badanych osób starszych w istotnym stopniu wzrastała również ich jakość życia w analizowanym wymiarze (Tabela 10).

\section{Tabela 10. Zmienne niezależne warunkujące jakość życia w wymiarze zdrowia psychicznego według modelu regresji liniowej}

\begin{tabular}{|l|r|r|r|c|}
\hline \multicolumn{1}{|c|}{ Zmienne niezależne } & \multicolumn{1}{c|}{$\boldsymbol{B}$} & \multicolumn{2}{c|}{$\mathbf{9 5 \%} \boldsymbol{C I}$} & $\boldsymbol{p}$ \\
\hline Praca w gospodarstwie rolnym (nie $v$ s tak) & $-4,44$ & $-8,35$ & $-0,53$ & $<0,05$ \\
\hline Problem braku wsparcia (nie $v s$ tak) & 3,41 & 1,22 & 5,60 & $<0,05$ \\
\hline Średnia częstość wszystkich dolegliwości & $-6,34$ & $-10,36$ & $-2,32$ & $<0,05$ \\
\hline Satysfakcja życiowa mierzona skalą LSITA SF & 1,01 & 0,77 & 1,25 & $<0,05$ \\
\hline
\end{tabular}

B - współczynnik regresji, 95\% Cl - zakres przedziału ufności dla B.

Źródło: opracowanie własne

\section{Dyskusja}

Obserwowany w ostatnich latach wzrost zainteresowania badaniami nad jakością życia uwarunkowaną stanem zdrowia osób starszych podyktowany jest postępującym procesem starzenia się społeczeństwa, a tym samym wzrostem liczby osób przewlekle chorych o specyficznych problemach zdrowotnych i społecznych. Jednakże większość prowadzonych badań dotykających tej tematyki koncentruje się na populacji miejskiej lub generalnej, a tylko w niewielkim stopniu pokazuje, jakie czynniki wpływają na jakość życia uwarunkowaną stanem zdrowia seniorów zamieszkujących obszary wiejskie, gdzie - jak donoszą dotychczasowe publikacje - występuje kumulacja trudnych sytuacji życiowych, szczególnie dla osób w starszym wieku.

Spośród ośmiu analizowanych wskaźników jakości życia uwarunkowanej stanem zdrowia najwyżej oceniane przez badane osoby starsze mieszkające na wsi były: zdolność do pełnienia ról pomimo ograniczeń w stanie emocjonalnym, zdrowie psychiczne, funkcjonowanie bez ograniczeń w życiu towarzyskim oraz wigor i energia. Natomiast najgorszą jakość życia seniorzy potwierdzali w odniesieniu do: zdolności do pełnienia ról pomimo ograniczeń w stanie zdrowia, funkcjonowania pomimo występujących objawów bólowych oraz stanu funkcjonalnego. W badaniach przeprowadzonych przez Osborne’a i współautorów (2003) w grupie 1056 osób w wieku 60 lat i więcej mieszkających w Australii także wykazano najwyższą ocenę HRQoL w wymiarze zdolności do pełnie- 
nia ról pomimo ograniczeń w stanie emocjonalnym, zdrowia psychicznego oraz funkcjonowania bez ograniczeń w życiu towarzyskim. Wymiar funkcjonowania bez ograniczeń w życiu towarzyskim został oceniony wysoko w badaniach przeprowadzonych w Brazylii w grupie 1958 osób, których średni wiek wynosił 69,6 lat (Guimaraes-Lima i wsp., 2009). Podobnie wysokie oceny dotyczyły zdolności do pełnienia ról pomimo ograniczeń w stanie zdrowia oraz w stanie emocjonalnym.

W świetle uzyskanych wyników badań własnych można wnioskować, że osoby starsze mieszkające na wsi istotnie lepiej oceniły jakość życia warunkowaną stanem zdrowia w wymiarze psychicznym niż fizycznym. Tendencję do lepszej oceny jakości życia uwarunkowanej stanem zdrowia w wymiarze psychicznym niż fizycznym potwierdziły także badania przeprowadzone w Polsce przez Zagożdżona, Kolarzyk i Marcinkowskiego (2011) w grupie 1560 kobiet w wieku 45-60 lat mieszkających na wsi. Podobną prawidłowość wykazano również w badaniach wykonanych w Iranie w grupie 1000 osób w wieku 60 lat i więcej (Aghamolaei, Zare, Tavafian, 2010) oraz we wspomnianej już Australii (Osborne i wsp., 2003). W projekcie PolSenior (Waszkiewicz, Einhorn, Połtyn-Zaradna, 2012), porównując jakość życia starszych mieszkańców wsi i miasta, zauważono, iż seniorzy mieszkający w mieście charakteryzowali się lepszą jakością życia w dziedzinie fizycznej (codzienne funkcjonowanie, energia życiowa, mobilność, odczuwanie bólu) i psychospołecznej (zadowolenie z życia i samego siebie, poczucie sensu życia) w porównaniu do starszych mieszkańców wsi. Tymczasem mieszkańcy wsi potwierdzali wyższą jakość życia w dziedzinie relacji społecznych i środowiskowych niż osoby mieszkające w mieście.

Badania własne wykazały, że mężczyźni istotnie lepiej oceniali jakość życia uwarunkowaną stenem zdrowia w wymiarze stanu funkcjonalnego, zdolności do pełnienia ról pomimo ograniczeń w stanie zdrowia oraz wigoru i energii. Literatura przedmiotu także potwierdza skłonność kobiet do gorszej oceny HRQoL (Walters, Murno, Brazjer, 2001; Guallar-Castillona, Sendinoa, Banegas, 2005; Belvis i wsp., 2008; Guimaraes-Lima i wsp., 2009; Aghamolaei, Zare, Tavafian, 2010). Gorsza ocena jakości życia uwarunkowanej stanem zdrowia dokonywana przez kobiety może wynikać z ich uwarunkowań fizjologicznych (geny, anatomia, hormony) i psychospołecznych (przypisywana rola, gorsze wykształcenie i zasoby materialne) (Dalh, Birkelund, 1997; Singh, Dixit, 2010). Guallar-Castillona, Sendinoa i Banegas (2005) wykazali, iż genderowe zróżnicowanie w ocenie HRQoL wynikało $\mathrm{z}$ faktu, iż kobiety charakteryzowały się niższym poziomem wykształcenia, mniejszą aktywnością fizyczną oraz wyższym wskaźnikiem BMI niż mężczyźni.

Jeśli chodzi o sytuację zawodową badanych, to większość stanowiły osoby pracujące $\mathrm{w}$ przeszłości w gospodarstwie rolnym, podobnie jak w projekcie zrealizowanym pod kierownictwem Synaka (Halicka, Halicki, 2002). Badania własne wykazały, że wśród osób pracujących w przeszłości w rolnictwie istotnie częściej 
występowały choroby układu krążenia, pokarmowego i naczyniowego oraz zaburzenia sensoryczne niż u respondentów nigdy niezwiązanych z rolnictwem. Model regresji liniowej wskazał istotną relację pomiędzy wymiarem funkcjonowania bez ograniczeń w życiu towarzyskim, wigoru i energii oraz zdrowia psychicznego a pracą $\mathrm{w}$ rolnictwie: osoby pracujące $\mathrm{w}$ przeszłości w rolnictwie charakteryzowały się lepszą HRQoL w tych wymiarach w porównaniu do respondentów nigdy niepracujących w rolnictwie.

Wiek przejścia na emeryturę badanych seniorów rzutował na ich jakość życia uwarunkowaną stanem zdrowia w wymiarze funkcjonalnym: im późniejszy wiek przejścia na emeryturę, tym lepsza jakość życia w tym wymiarze. Liczne doniesienia potwierdzają, iż zaprzestanie aktywności zawodowej po przejściu na emeryturę u osób starszych często wiąże się z utratą sensu życia oraz utratą więzi emocjonalnych z otoczeniem i narastającym poczuciem bezradności (Trafiałek, 2003). W badaniach Synaka (Halicka, Halicki, 2002), pokazano, że pomimo iż po przejściu na emeryturę/rentę osoby starsze najczęściej wyrażały zadowolenie z tego faktu, to jednak ich wysoki odsetek zgłaszał także zatroskanie i zmartwienie z powodu zaprzestania pracy. Ponadto badani seniorzy przyznali, że po przejściu w stan spoczynku zawodowego najbardziej brakuje im zarobków i kontaktów z ludźmi.

Przeprowadzone badania pozwoliły spojrzeć z szerszej perspektywy na jakość życia uwarunkowaną stanem zdrowia osób starszych, z uwzględnieniem ważniejszych aspektów ich życia. Umożliwiły także kompleksowo ocenić stan zdrowia seniorów mieszkających na wsi, standard ich życia oraz zajmowaną pozycję w społeczeństwie. Wykazano, że niezależnymi determinantami jakości życia uwarunkowanej stanem zdrowia seniorów zamieszkujących obszary wiejskie były: płeć, wiek, sytuacja rodzinna, warunki mieszkaniowe i sytuacja materialna, stopień powiązania w przeszłości z rolnictwem, stan zdrowia, sprawność funkcjonalna, ryzyko niedożywienia, rodzaj otrzymywanego wsparcia oraz poziom satysfakcji życiowej. Należy jednak podkreślić, iż uzyskane wyniki dotyczą tylko pewnego wycinka populacji osób starszych - zamieszkujących wyłącznie województwo małopolskie. Dla pełnego zobrazowania analizowanego zagadnienia wskazane byłyby badania dotyczące całej populacji osób w wieku 65 lat i więcej, zamieszkujących tereny wiejskie w Polsce - tym bardziej że istniejące prognozy wskazują, iż problemy towarzyszące osobom starszym mieszkającym na obszarach wiejskich będą pogłębiać się i ulegać ustawicznym zamianom. Uzyskane wyniki mogłyby natomiast posłużyć do wypracowania odpowiedniej strategii rozpoznawania i zapobiegania piętrzącym się problemom w grupie osób starszych mieszkających na wsi. Ponadto, aby wykazać pewne zróżnicowanie czynników warunkujących jakość życia uwarunkowaną stanem zdrowia seniorów, należy przeprowadzić badania porównawcze pomiędzy starszymi mieszkańcami wsi i miasta. Dotychczasowe badania wskazują bowiem, iż starsi mieszkańcy wsi, w porównaniu do seniorów mieszkających w miastach, charakteryzują się niższą jakością życia, uwarunko- 
waną gorszym stanem zdrowia (subiektywnym i obiektywnym), gorszą sytuacją materialną i mieszkaniową oraz gorszym dostępem do usług medycznych (podstawowych i specjalistycznych). Dzięki badaniom porównawczym sondowanie, które czynniki decydują o jakości życia uwarunkowanej stanem zdrowia, będzie trafniejsze.

\section{Bibliografia}

Aghamolaei T., Zare S., Tavafian S. S. (2010), Health Related Quality of Life in Elderly People Living in Bandar Abbas, Iran: A Population-Based Study, „Acta Medica Iranica”, t. 48, nr 3, s. $185-191$.

Barrett A.J., Murk P.J. (2006), Life Satisfaction Index for the Third Age (LSITA): A Measurement of Successful Aging, [w:] E.P. Isaac (red.), Proceedings of the 2006 Midwest Research-to-Practice Conference in Adult. Continuing, and Community Education, University of Missouri, St. Louis, s. 7-12.

Barrocas A., White J.V., Gomez C., Smithwick L. (1996), Assessing health status in the elderly: the nutrition screening initiative, ,Journal of Health Care for the Poor and Underserved”, t. 7, nr 3, s. 210-218.

Belvis A. G., Avolio A., Spagnolo A., Damiani G. S. (2008), Factors associated with health-related quality of life: the role of social relationships among the elderly in an Italian region, „Public Health", t. 122, nr 8, s. 784-793.

Benjamin-Coleman R., Alexy B. (1999), Use of the SF-36 to identify community dwelling rural elderly at risk for hospitalization, „Public Health Nurs”, t. 16, s. 223-227.

Borders T.F., Aday L.A. (2004), Factors associated with health-related quality of life among an older population in a largely rural western region, „Journal Rural Health”, t. 20, nr 1, s. 67-75.

Campbell A., Converse P.E., Rodgers W.L. (1976), The Quality of American Life: Perceptions, Evaluations, and Satisfaction, Russell Sage, New York.

Dalh E., Birkelund G.E. (1997), Health inequalities in later life in a social democratic welfare state, „Social Science and Medicine”, t. 39, s. 871-881.

Goins R. T., Mitchell J. (1999), Health-related quality of life: does rurality matter?, „Journal Rural Health", t. 15 , nr 1, s. 147-156.

Guallar-Castillona P., Sendinoa A.R., Banegas J.R. (2005), Differences in quality of life between women and men in the older population of Spain, „Social Science and Medicine”, t. 60, nr 6, s. $1229-1240$.

Guimaraes-Lima M., Barros M.B., Cesar C.L., Goldbaum M. (2009), Health related quality of life among the elderly: population based study using SF-36 survey, „Cad Saude Publica, Rio de Janerio", t. 25, nr 10, s. 2159-2167.

Halicka M., Halicki J. (2002), Praca zawodowa i jej znaczenie w życiu czlowieka starego, [w:] B. Synak (red.), Polska starość, Wydawnictwo Uniwersytetu Gdańskiego, Gdańsk, s. 173-188.

Hornquist J. O. (1980), The concept of quality of life, „Scandinavian Journal of Social Medicine”, t. 10, s. $57-61$.

Kempen G.I., Miedema I., Ormel J., Molenaar W. (1996), The assessment of disability with the Groningen Activity Restriction Scale. Conceptual framework and psychometric properties, „Social Science and Medicine”, t. 43, nr 11, s. 1601-1610.

Magilvy J.K., Congdon J.G. (2000), The crisis of health care transitions for rural older adults, „Public Health Nursing”, t. 17, nr 5, s. 336-345. 
Marcinowicz L., Sienkiewicz J. (2003), Badanie trafności i rzetelności polskiej wersji kwestionariusza SF-36: wyniki wstępne, „Przegląd Lekarski”, t. 67, nr 12, s. 103-106.

Osborne R.H., Hawthorne G., Lew E., Gray L.C. (2003), Quality of life assessment in the community-dwelling elderly: Validation of the Assessment of Quality of Life (AQoL) Instrument and comparison with the SF-36, „Journal of Clinical Epidemiology”, t. 56, nr 2, s. 138-147.

Ostrzyżek A., Marcinkowski J.T. (2012), Jakość życia jako pozytywny wskaźnik zdrowia, „Hygeia Public Health", t. 47, nr 4, s. 408-411.

Rozporządzenie Rady Ministrów z dnia 4 sierpnia 2016 r. w sprawie Narodowego Programu Zdrowia na lata 2016-2020.

Schipper H. (1990), Quality of life: principles of the clinical paradigm, „Journal of Psychosocial Oncology", nr 8, s. 171-185.

Sherbourne C.D., Stewart A.L. (1991), The MOS social support survey, ,Social Science and Medicine", t. 6, nr 32, s. 705-714.

Singh R., Dixit S. (2010), Health-Related Quality of Life and Health Management, ,Journal of Health Management", t. 12, nr 2, s. 153-172.

Trafiałek E. (2003), Polska starość w dobie przemian, Wydawnictwo Śląsk, Katowice.

Tryfan B. (1993), Wiejska starość w Europie, Polska Akademia Nauk. Instytut Rozwoju Wsi i Rolnictwa, Warszawa.

Walters S.J., Murno J.F., Brazjer J.E. (2001), Using the SF-36 with older adults: a cross-sectional community based Survey, „Age Ageing”, t. 30, nr 4, s. 337-343.

Ware J.E., Sherbourne C.D. (1992), The MOS 36-item short-form health survey (SF-36): conceptual framework and item selection, „Medical Care”, t. 30, nr 6, s. 473-483.

Waszkiewicz L., Einhorn J., Połtyn-Zaradna K. (2012), Ocena jakości życia Polaków w wieku podeszłym, [w:] M. Mossakowska, A. Więcek, P. Błędowski (red.), Aspekty medyczne, psychologiczne, socjologiczne i ekonomiczne starzenia się ludzi w Polsce, Termedia Wydawnictwo Medyczne, Poznań, s. 549-561.

Wojszel Z.B. (2009), Geriatryczne zespoły niesprawności i ustugi opiekuńcze w późnej starości. Analiza wielowymiarowa na przyktadzie wybranych środowisk województwa podlaskiego, Trans Humana, Białystok.

Zagożdżon P., Kolarzyk E., Marcinkowski J.T. (2011), Quality of life and rural place of residence in Polish women-population based study, ,Annals of Agricultural and Environmental Medicine", t. 18, nr 2, s. 429-432. 


\section{Analysis of the Health Related Quality of Life Elderly People Living in Rural Areas}

Abstract: In connection with the aging of the population and the increase in the number of people with chronic illnesses, the priority objective for health care has become not only lengthening life, but also improving quality of life in older persons, as well as maintenance of their relative independence and active participation in social life. The most important factor in determining quality of life is health. Therefore, within this concept is used the term 'health related quality of life' which means quality of life designated state of health, current illnesses and the natural ageing process.

The main goal of the present study was to investigate the health related quality of life of elderly people living in rural areas and to identify its determinants.

The group of respondents consisted 203 people aged 65 years and over living in rural areas in Małopolska. The analysis of collected research material was performed using the statistical package SPSS 19 for Windows. The level of significance for the tested the hypotheses assumed value of 0.05.

Elderly people who living in rural areas showed lower health related quality of life in physical dimension than in psychological dimension. The factors that determined this assessment including: sex, age, family situation, housing and financial situation, agricultural work in the past, health status, functional state, the risk of malnutrition, the type of the support and the level of life satisfaction of respondents.

Keywords: health related quality of life, older people, rural areas

JEL: $110,114,118$

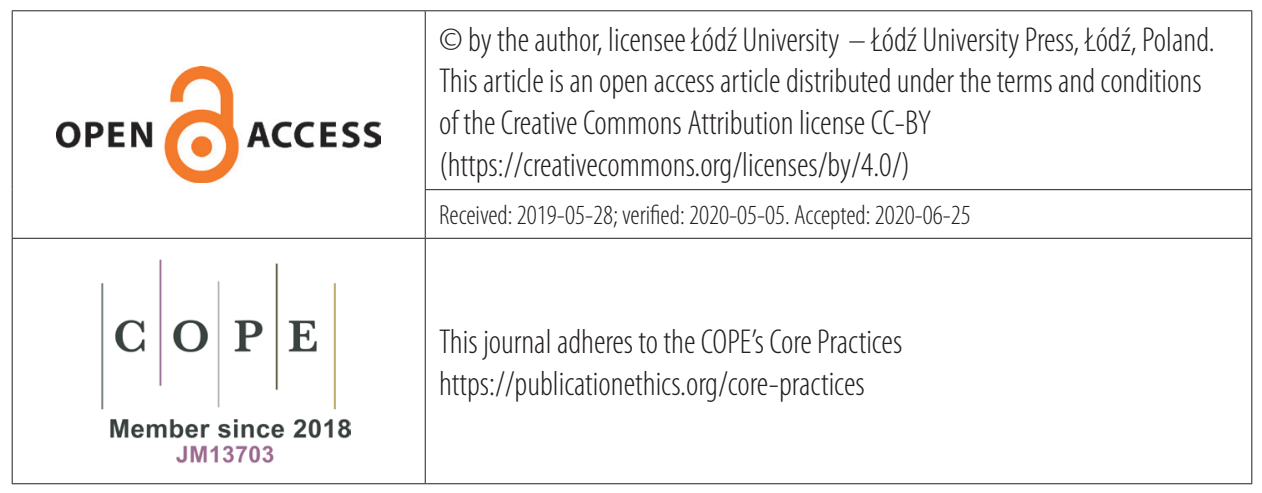

